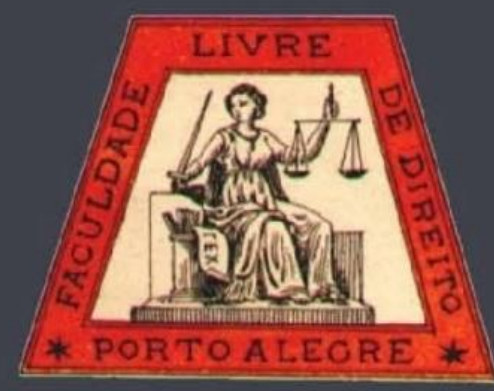

\title{
Redução do espaço de atuação discricionária da Administração nos atos administrativos de nomeação de cargos e empregos através de concurso público
}

Space Reduction of the Administration Discretionary Action in the Administrative Acts of Appointment for Public Employments through Public Tender

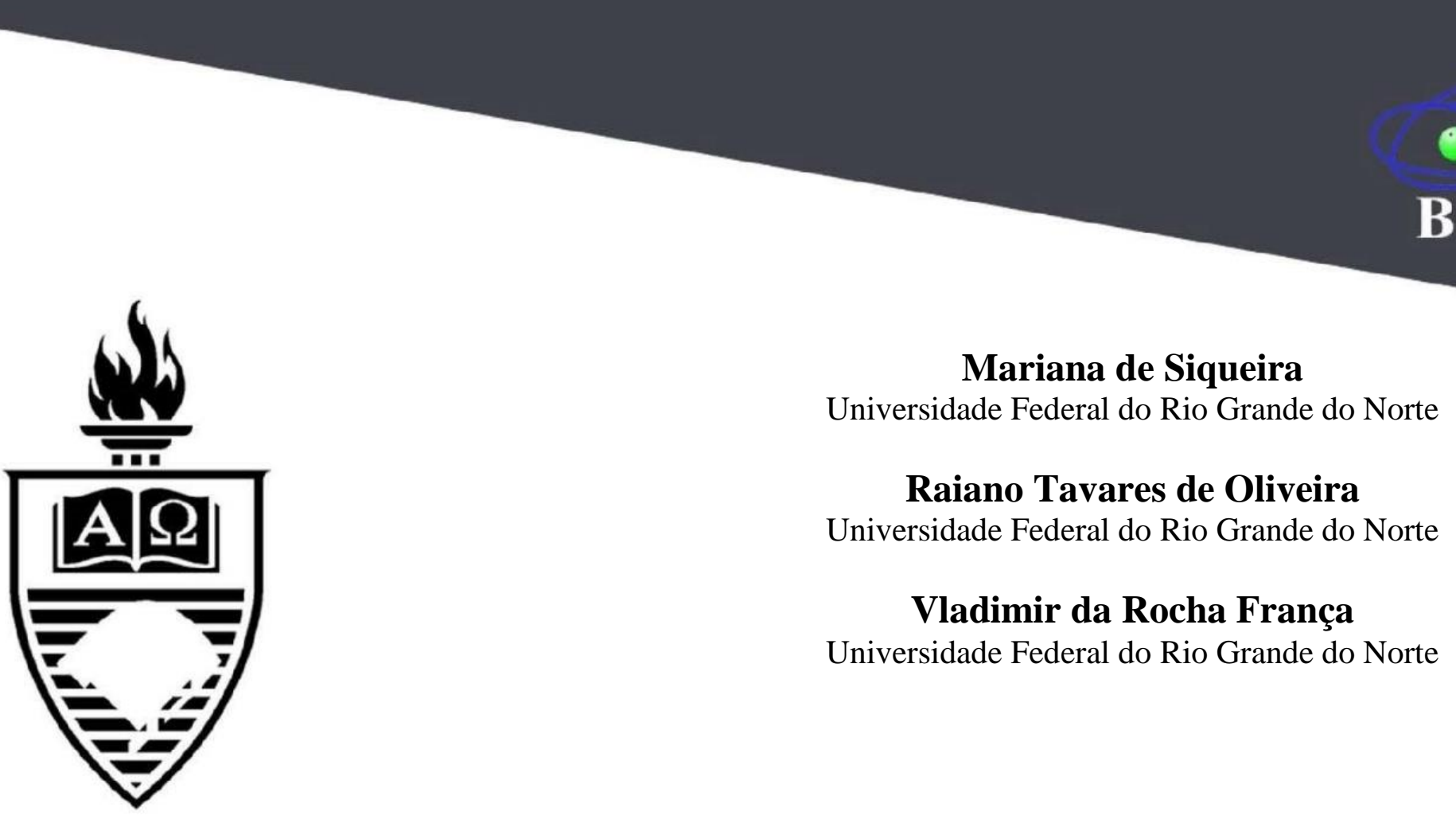

\section{UFRGS}




\title{
Redução do espaço de atuação discricionária da Administração nos atos administrativos de nomeação de cargos e empregos através de concurso público
}

\author{
Space Reduction of the Administration Discretionary Action in the Administrative Acts of Appoint- \\ ment for Public Employments through Public Tender
}

Mariana de Siqueira*

Raiano Tavares de Oliveira* ${ }^{* *}$

Vladimir da Rocha França ${ }^{* * *}$

\section{REFERÊNCIA}

SIQUEIRA, Mariana de; OLIVEIRA, Raiano Tavares de; FRANÇA, Vladimir da Rocha. Redução do espaço de atuação discricionária da Administração nos atos administrativos de nomeação de cargos e empregos através de concurso público. Revista da Faculdade de Direito da UFRGS, Porto Alegre, n. 37, p. 219-238, dez. 2017.

\begin{abstract}
RESUMO
O presente artigo se propõe a discutir a possibilidade da redução da atuação discricionária do Administrador Público na nomeação de candidatos aprovados em concurso público a patamares tão baixos que, por consequência, geraria um direito subjetivo à nomeação. Para tanto, fala-se sobre os limites da análise do mérito administrativo pelo Poder Judiciário; depois comenta-se, brevemente, sobre a evolução jurisprudencial do direito à nomeação para cargos e empregos públicos e, por fim, discute-se a possibilidade da redução da atuação discricionária do gestor no caso de candidato aprovado em cadastro de reserva, exemplificando com recente julgado do STF sobre o tema, qual seja o RE 837.311/PI, publicado em 18 de abril de 2016. No campo da metodologia, recorreu-se à ampla pesquisa bibliográfica, por meio de livros, artigos científicos, periódicos, jurisprudências e súmulas sobre o tema em tela. Conclui-se pela possibilidade de reduzir o campo de atuação discricionária do Administrador Público quando há desrespeito, no caso concreto, aos princípios norteadores da Administração Pública.
\end{abstract}

\section{PALAVRAS-CHAVE}

Discricionariedade. Ato Administrativo. Nomeação. Concurso Público.

\section{ABSTRACT}

The present article proposes to discuss the possibility of reducing the discretionary action of the Public Administrator in the nomination of candidates approved in public tender to levels so low that, consequently, it would generate a subjective right to the appointment. In order to do so, it is discussed the limits of the analysis of administrative merit (substance) by the Judiciary, then, it is briefly commented on the case law evolution on the right to appointment for public jobs and, finally, the possibility of the reduction of the Administrator discretionary action in the case of a candidate approved in a reserve register, exemplifying with recent STF decision on the subject, in the case RE 837.311/PI, published on April 18th, 2016. In terms of methodology, it was used bibliographical research, through books, scientific articles, periodicals, case law and pronouncements on the subject. It concludes by the possibility of reducing the discretion of the Public Administrator when there is a disregard, in a concrete case, to the guiding principles of the Public Administration.

\section{KEYWORDS}

Discretionary. Administrative act. Appointment. Public tender.

\footnotetext{
* Professora da Universidade Federal do Rio Grande do Norte (UFRN). Doutora em Direito Público (Universidade Federal de Pernambuco - UFPE, 2014). Mestre em Direito (UFRN, 2009). Graduada em Direito (UFRN, 2006).

${ }^{* *}$ Mestrando em Direito Constitucional (Universidade Federal do Rio Grande do Norte - UFRN). Especialista em Direito Administrativo (UFRN, 2017). Graduado em Direito (UFRN, 2015).

${ }^{* * * *}$ Professor da Universidade Federal do Rio Grande do Norte (UFRN). Doutor em Direito (Pontifícia Universidade Católica de São Paulo - PUC-SP, 2004). Mestre em Direito (Universidade Federal de Pernambuco - UFPE, 1998). Graduado em Direito (UFRN, 1995).
} 


\section{SUMÁRIO}

Introdução. 1. A (im)possibilidade do controle do mérito administrativo pelo Poder Judiciário. 2. Breve evolução jurisprudencial sobre o direito subjetivo à nomeação de candidatos aprovados em concurso público. 3. Redução do espaço de discricionariedade na atuação da administração no caso de nomeação de candidato aprovado em concurso público no cadastro de reserva: o caso do recurso extraordinário 837.311/PI. Conclusão. Referências.

\section{INTRODUÇÃO}

O instituto do concurso público no Brasil tomou a sua forma mais robusta com a Constituição Federal de 1988. Plasmado no inciso II do art. 37, a Lei Maior leciona que, somente através desse instituto, é possível a investidura em cargos ou empregos públicos, ressalvadas as nomeações para cargos em comissões.

Esse inciso dá coesão aos princípios que regem a Administração Pública, explicitados no caput do artigo supracitado, em especial, ao da impessoalidade, ao da moralidade e ao da eficiência, além de respeitar o da igualdade, em que todos são iguais perante a lei, sem distinção de qualquer natureza (art. $5^{\circ}$, caput, CRFB/88).

O constituinte originário desejou, pois, que o acesso aos cargos e empregos públicos ocorresse de forma igualitária em que todos os candidatos poderiam concorrer do mesmo ponto de partida, aniquilando qualquer possibilidade, em tese, de apadrinhamento para se obter uma posição laboral efetiva na Administração Pública.

Busca-se, assim, o candidato que possua o melhor desempenho intelectual frente a todos os outros candidatos, isto é, o mais eficiente e capaz diante das exigências do edital, a fim de que seja empossado ou contratado para fazer parte de algum órgão governamental.

A estabilidade no cargo público, a solidez das empresas públicas, a qualidade de vida no trabalho, os salários e os auxílios peculiares de cada órgão são algumas das características que movem inúmeros brasileiros a se dedicarem em busca da aprovação num concurso público.

Devido ao alto esforço físico, emocional e até financeiro necessários e por se tornar um processo seletivo cada vez mais acirrado devido à alta concorrência, aqueles que logram êxito nas provas do certame não hesitam, se necessário e a depender do caso concreto, em se valer do Poder Judiciário ${ }^{1}$ para obter a sua nomeação caso compreendam que a Administração Pública tenha preterido os aprovados de alguma forma.

Além de todo o caminho percorrido, a aprovação ou classificação no certame não significa, em alguns casos, a sua nomeação, restando o ato administrativo de convocar o candidato como discricionário, de acordo com a necessidade e conveniência do gestor.

Diante de alguns fatores tidos como injustos, como a preterição, a contratação precária para realizar mesma função que houve concurso, a abertura de novo certame para o mesmo cargo com a existência de aprovados em cadastro de reserva etc., milhares ${ }^{2}$ de candidatos ingressam com ações judiciais, buscando seu direito à nomeação, tornando o ato, antes discricionário, vinculado diante do caso concreto.

Durante muito tempo, perdurou a ideia de que a nomeação de aprovados - até mesmo dentro do número de vagas - seria um ato discricionário,

\footnotetext{
${ }^{1}$ Ao se realizar uma pesquisa jurisprudencial no site do STF com os termos "concurso público" e "nomeação" com um lapso temporal dos último cinco anos, resulta-se num quantitativo de 286 acórdãos e 2477 decisões monocráticas. No STJ, utilizando-se os mesmos critérios, tem-se 1045 acórdãos.

${ }^{2}$ No âmbito regional, por exemplo, o Tribunal de Justiça do Rio Grande do Norte julgou 3.296 processos nos últimos cinco anos sobre o tema concurso público e direito à nomeação. Dado obtido através da consulta jurisprudencial do e-SAJ TJ/RN. Disponível em: <http://esaj.tjrn.jus.br/cjosg/>. Acesso em: 19 out. 2017.
} 
afirmando que se tem apenas uma mera expectativa de direito à nomeação ${ }^{3}$. A Administração Pública, logo, não era obrigada a convocar os aprovados, ficando estes à mercê dos critérios de conveniência e oportunidade do gestor.

Enquanto de um lado a Administração Pública defende que não cometeu abusos e, em matéria de nomeação, seus atos administrativos são discricionários, ou melhor, que tais atos possuem baixo grau de vinculação à juridicidade ${ }^{4}$, há, do outro, o indivíduo participante do certame que afirma ter direito subjetivo, devendo o ato administrativo de nomeação ser vinculado perante determinada situação fática a qual está inserido.

Assim, este artigo se propõe a apresentar essa problemática e analisar a possibilidade, diante da análise jurisprudencial, em especial, da decisão proferida pelo Supremo Tribunal Federal no RE 837.311/PI, da redução do espaço de atuação discricionária do Poder Público nos atos de nomeação para cargos e empregos públicos realizados através do instituto aqui tratado.

\section{A (IM)POSSIBILIDADE DO CONTROLE DO MÉRITO ADMINISTRATIVO PELO PO- DER JUDICIÁRIO}

Diante da dinamicidade do sistema político, social e o econômico ${ }^{5}$, não seria possível prever, nas normas legais, todas as situações e ações que a Administração Pública poderia viver no seu dia a dia.

Seria até utópico pensar que seria possível e até humano - regular e descrever todas as formas e as situações dos agentes públicos. Assim, confere-se à Administração a possibilidade de realizar

${ }^{3}$ TOURINHO, Rita. O Concurso Público no Ordenamento Jurídico Brasileiro. 1 ed. Rio de Janeiro: Lumen Juris, 2009. p. 94.

${ }^{4}$ BINENBOJM, Gustavo. Uma teoria do direito administrativo: direitos fundamentais, democracia e constitucionalização. 3. ed. Rio de Janeiro: Renovar, 2014.

${ }^{5}$ GUERRA, Sérgio. Discricionariedade administrativa - Limitações da vinculação legalitária e propostas pós-positivistas. In: ARAGÃO, Alexandre Santos de; MARQUES escolhas dentro de uma moldura legal já prevista, evitando-se opções arbitrárias e contrárias ao interesse público. Pode-se dizer que haveria um certo protagonismo político nesse momento de maior liberdade de escolha ${ }^{6}$.

Assim, não se pode afirmar que a atividade administrativa se limita apenas a executar o que a lei positivada prevê. O gestor não remonta aos tempos da França pós-revolução em que o juiz era mera "boca da lei", aplicando, de forma mecânica, a norma positivada nos seus exatos dizeres.

Tal atividade deve, portanto, gerir os interesses públicos diversos de forma que tente, dentro da realidade e das possibilidades dadas, satisfazer os anseios da sociedade através da aplicação do ordenamento jurídico ${ }^{7}$, fazendo-se valer, quando permitido e possível, dos espaços e aberturas para uma atuação criativa - porém dentro dos limites da lei.

Utilizando-se das lições de Celso Antônio Bandeira de Mello $^{8}$, discricionariedade seria a margem, isto é, uma possibilidade de certa liberdade facultada ao administrador para eleger, segundo critérios firmes de razoabilidade, uma, dentre pelo menos duas opções, cabíveis diante do caso concreto, com o objetivo de adotar a solução mais adequada, a fim de satisfazer a finalidade legal.

Ademais, essa situação de escolha apenas se faz possível quando a lei possui termos fluidos ou permite tal liberdade e não se possa extrair, objetivamente, uma única solução para o caso concreto.

NETO, Floriano de Azevedo (Coord.). Direito administrativo e seus novos paradigmas. Belo Horizonte: Fórum, 2012, p. 205-240. p. 212.

${ }^{6}$ GUERRA, op. cit., p. 212.

${ }^{7}$ MORÓN, Miguel Sánchez. Discrecionalidad administrativa y control judicial, $1^{\mathrm{a}}$ ed. Madrid: Tecnos, 1995. p. 31.

${ }^{8}$ MELLO, Celso Antônio Bandeira de. Curso de direito administrativo. 30. ed. São Paulo: Malheiros, 2013. p. 988. 
Maria Sylvia Zanella de Pietro ${ }^{9}$ leciona no mesmo sentido, afirmando que, como o legislador não teria possibilidade de prever e avaliar todas as situações possíveis, foi obrigado a deixar certa margem de liberdade para a Administração apreciar os casos concretos de acordo com critérios próprios, a fim de escolher a melhor alternativa dentre as possíveis, balizando-se pela proteção ao interesse público.

Frente às explicações doutrinárias aqui mencionadas, depreende-se que a atuação discricionária não se relaciona com a vontade arbitrária do administrador. Seus desejos egoísticos - voltados para um interesse próprio ou de um pequeno grupo - não representam o objetivo da existência dessa possibilidade de se escolher um determinado caminho diante de duas ou mais opções.

Conforme leciona Jean-Claude Ricci ${ }^{10}$, a Administração não está, inteiramente, vinculada de um lado. Ela dispõe de certa liberdade e, por outro, ela não está, completamente, livre para atuar da forma que deseja a depender do seu humor ou de seus caprichos. Exige-se respeito a um mínimo de regras jurídicas.

Percebe-se que a discricionariedade aqui discutida está, intimamente, ligada e coesa com o Direito Administrativo Contemporâneo, isto é, ela não está, completamente, livre e irrestrita. Está, na verdade, conectada a premissas legais, gerando, por consequência, limitações.

Esses limites são os freios que controlam interpretações dissociadas da realidade fática. Há uma ligação da discricionariedade com a lei e com o Direito, conforme leciona Hartmut Maurer:

\footnotetext{
${ }^{9}$ DI PIETRO, Maria Sylvia Zanella. Discricionariedade administrativa na Constituição de 1988. 3. ed. São Paulo: Atlas, 2012. p. 14.

${ }^{10}$ RICCI, Jean-Claude. Droit Admnistratif Général. 5e Edition. Paris: Hachette Supeieur, 2013.p. 41.

${ }^{11}$ MAURER, Hartmut. Allgemeines Verwaltungsrecht. 15 Auflage. München: Verlag Beck, 2004, p. 139.
}

Não existe uma discricionariedade livre (muito embora esta equivocada formulação ainda seja ocasionalmente publicada nos dias de hoje), mas uma discricionariedade dever, ou melhor: uma discricionariedade vinculada ao Direito. ${ }^{11}$

Tradicionalmente, diz-se que, na ação discricionária, o administrador possui o poder de escolha baseado no binômio conveniência e oportunidade, cuja análise de mérito do ato administrativo não poderia ser apreciada pelo Poder Judiciário ${ }^{12}$.

Assim, tomando como base o seu entendimento e sua capacidade resolutiva, o administrador público escolhe a opção que, naquele momento, entende ser a melhor para que a efetivação da finalidade pública seja alcançada.

Entretanto, essa visão evoluiu e o clássico critério de conveniência e de oportunidade não mais satisfaz, completamente, a comunidade jurídica.

Assim, seguindo o pensamento de Karl Engisch $^{13}$, há uma ligação íntima entre o eixo de atuação e as balizas da discricionariedade, devendo compreender não somente o famoso binômio, mas também os direitos e garantias fundamentais dos cidadãos.

Corroborando com esse pensamento, Odete Medauar compreende, nesse sentido, a necessidade da redução do espaço de discricionariedade do administrador, colocando, em primeiro plano, o diálogo e o consenso para que surja, de fato, a melhor opção para o interesse público.

Ela afirma que:

A atividade de consenso-negociação entre Poder Público e particulares, mesmo informal, passa a assumir papel importante no processo de identificação e definição de interesses públicos e privados, tutelados pela Administração. Esta não mais

12 GUERRA, Sérgio. Discricionariedade Administrativo e sua Transformação no Estado Democrático de Direito. Revista da Faculdade de Direito Candido Mendes, Rio de Janeiro, v. 16, n. 16, p. 205-228, jan. 2011, p. 209. Disponível em: <http://www.ucam.edu.br/portal/images/PDFs/revista_fdcm/Ucam16.pdf $>$. Acesso em: 26/06/2017. ${ }^{13}$ ENGISCH, Karl. Introdução ao Pensamento Jurídico. $6^{\mathrm{a}}$ edição, Lisboa: Ed. Fundação Calouste Gulbenkian, 1988, p. 220. 
detém exclusividade no estabelecimento do interesse público: a discricionariedade se reduz, atenua-se a prática de imposição unilateral e autoritária de decisões. A Administração volta-se para a coletividade, passando a conhecer melhor os problemas e aspirações da sociedade. A Administração passa a ter atividade de mediação para dirimir e compor conflitos de interesses entre várias partes ou entre estas e a Administração ${ }^{14}$.

Entende-se, portanto, que a discricionariedade não pode ser dimensionada apenas pela conveniência e oportunidade do gestor, mas também pelos direitos fundamentais, pelo dever de boa-fé na Administração Pública, além dos princípios da eficiência, impessoalidade, moralidade e proteção à confiança - configurando total respeito ao Estado Democrático de Direito e ao instituto do concurso público.

Convém, nesse momento, discorrer sobre a possibilidade do controle dos atos administrativos discricionários ou, como leciona Celso Antônio Bandeira de Mello $^{15}$, dos atos praticados no exercício da competência discricionária.

Quando o legislador concedeu a competência discricionária à Administração, ele permitiu que se agisse segundo um limitado juízo subjetivo sobre a melhor decisão a ser tomada diante de um caso concreto, a fim de atender fins legais.

Essa liberdade, entretanto, possui limites impostos pelo ordenamento jurídico brasileiro, já que a atividade administrativa pode passar pela análise dos órgãos judiciais. Garante-se ao administrador liberdade de escolha, desde que não fira nem desrespeite os direitos de seus administrados.

\footnotetext{
${ }^{14}$ MEDAUAR, Odete. $O$ direito administrativo em evolução. $2^{\mathrm{a}}$ ed., São Paulo: RT, 2003, p. 211.

${ }^{15}$ MELLO, Celso Antônio Bandeira de. Curso de Direito Administrativo. 30. ed. São Paulo: Malheiros, 2013, p. 434.

${ }^{16}$ FRANÇA, Vladimir da Rocha. Estrutura e motivação do ato administrativo. São Paulo, Malheiros Editores, 2007. p. 57.

${ }^{17}$ Ibid, p. 58.

${ }^{18}$ FRANÇA, Vladimir da Rocha. Invalidação judicial da discricionariedade administrativa no regime jurídico-administrativo brasileiro. Rio de Janeiro, Forense, 2000. p. 4.
}

Importante fazer a ressalva de que a ação administrativa não se restringe a ser vinculada apenas à lei, mas a toda a ordem jurídica, incluindo a norma constitucional e as regras jurídicas existentes. Assim, o agir da Administração se pauta de acordo com a lei e com o Direito ${ }^{16}$.

Se isso não acontecesse, iria-se correr um grande risco de cerceamento de direitos. A Administração deve respeitar o princípio da legalidade, mas não pode se deter somente a ele.

Evidente que, devido ao princípio da inafastabilidade do poder jurisdicional, os atos administrativos podem ser questionados, no Poder Judiciário, em relação à sua juridicidade ${ }^{17}$.

Tal Poder possui, ademais, função e responsabilidade importantíssimas para que haja uma equilibrada Administração Pública democrática.

Os controlados pelo administrador - cuja hipossuficiência é infinitamente maior - recorrem ao magistrado a função de submeter a ação administrativa aos moldes do ordenamento jurídico. Nos casos em que a administração abusa de seus poderes por meio de seus atos comissivos ou omissivos, é de suma importância a atuação de um poder que possa reestabelecer a juridicidade dos seus atos ${ }^{18}$.

Assim, a tendência da doutrina ${ }^{19}$ é compreender a discricionariedade administrativa de forma ampla, abarcando a ideia de mérito administrativo, conceitos indeterminados e o entendimento sobre princípios.

O Poder Judiciário, dessa forma, quando analisa a discricionariedade administrativa, deve fazê-lo sob o ponto de vista da legalidade ampla, da sua correspondência com a norma e do mérito ${ }^{20}$.

${ }^{19}$ Como exemplo, pode-se citar: DI PIETRO, Maria Sylvia Zanella. Discricionariedade Administrativa na Constituição de 1988. São Paulo: Atlas, 1991, p. 94 e FILGUEIRAS JÚNIOR, Marcus Vinícius. Conceitos Jurídicos Indeterminados e Discricionariedade Administrativa. Rio de Janeiro: Lumen Juris, 2007. p. 172.

${ }^{20}$ Deve-se compreender que a análise do mérito aqui diz respeito à sua adequação ao ordenamento jurídico. Não se fala em usurpação das funções do Poder Executivo pelo Poder Judiciário. 
Importante esclarecer que, ao se falar da aná- motivos determinantes e o uso de conceitos indelise do mérito pelo Poder Judiciário, refere-se a terminados reclamam um olhar mais atencioso do uma averiguação perante os princípios explícitos e Judiciário frente ao mérito administrativo. Podeimplícitos do ordenamento jurídico, com o fito de se, assim, analisar a discricionariedade do ato, poaniquilar arbitrariedades, mas sem alterar o seu rém com o objetivo de conferir se a sua composimérito de fato.

Conforme entendimento do Superior Tribunal de Justiça $(\mathrm{STJ})^{21}$, o mérito em si não pode ser apreciado pelo Poder Judiciário. Vê-se:

Em relação ao controle jurisdicional do processo administrativo, a atuação do Poder Judiciário circunscreve-se ao campo da regularidade do procedimento, bem como à legalidade do ato demissionário, sendo-lhe defesa qualquer incursão no mérito administrativo, a fim de aferir o grau de conveniência e oportunidade. Precedentes. [...]. (Grifo nosso.)

O Supremo Tribunal Federal $(\mathrm{STF})^{22}$, também sobre o tema em tela, se manifestou conforme segue:

ção é compatível com o direito e a finalidade do ato.

Reforce-se que não significa, pois, a possibilidade desse Poder de modificar os juízos do binômio conveniência e oportunidade, mas, sim, de examinar os elementos supracitados e conferir se os limites da discricionariedade estão sendo respeitados. Tais limites não correspondem ao seu mérito propriamente dito, mas à sua legalidade ampla, isto é, à sua juridicidade.

\section{BREVE EVOLUÇÃO JURISPRUDENCIAL SOBRE O DIREITO SUBJETIVO À NOMEA- ÇÃO DE CANDIDATOS APROVADOS EM CONCURSO PÚBLICO}

\begin{abstract}
Mandado de Segurança. Procedimento administrativo. Contraditório e ampla defesa. 1. O art. $5^{\circ}$, LV, da CF ampliou o direito de defesa dos litigantes, para assegurar, em processo judicial e administrativo, aos acusados em geral, o contraditório e a ampla defesa, com os meios e os recursos a ela inerentes. Precedentes. 2. Cumpre ao Poder Judiciário, sem que tenha de apreciar necessariamente o mérito administrativo e examinar fatos e provas, exercer o controle jurisdicional do cumprimento desses princípios. 3. Recurso provido. (Grifo nosso.)
\end{abstract}

Em conclusão, os princípios, em especial, o da juridicidade, o da moralidade e o da razoabilidade, as concepções existentes sobre a teoria dos
Da década de 50 até mesmo vinte anos depois da promulgação da Constituição da República de 1988, que elevou o instituto do concurso público como instrumento democrático para o provimento de cargos e empregos públicos efetivos, o Supremo Tribunal Federal manteve uma posição clássica de reconhecer ao candidato aprovado em certame público somente uma mera expectativa de direito $^{23}$.

Assim, o ato administrativo de nomear dependia, tão somente, da discricionariedade administrativa do gestor do órgão, que, pautando-se na

\footnotetext{
${ }^{21}$ BRASIL. Superior Tribunal de Justiça. RMS 20.481 / MT, aprovado em concurso público torna-se detentor de mera exRelator Ministro Gilson Dipp, julgamento no dia pectativa de direito, não de direito à nomeação: preceden17/08/2006, Órgão julgador a quinta turma - T5, publicado tes. O termo dos períodos de suspensão das nomeações na no Diário de Justiça do dia 11/09/2006, na página 316.

${ }^{22}$ BRASIL. Supremo Tribunal Federal. RMS 24.823, DF, Relatora Ministra Ellen Gracie, julgamento dia 18/04/2006, Órgão julgador segunda turma, publicado no Diário de Justiça do dia 19/05/2006.

${ }^{23}$ Como exemplo, pode-se citar a seguinte ementa:

Concurso público: direito à nomeação: Súmula 15-STF. Firmou-se o entendimento do STF no sentido de que o candidato esfera da Administração Federal, ainda quando determinado por decretos editados no prazo de validade do concurso, não implica, por si só, na prorrogação desse mesmo prazo de validade pelo tempo correspondente à suspensão. (AI 501573 AgR, Relator(a): Min. SEPÚLVEDA PERTENCE, Primeira Turma, julgado em 12/04/2005, DJ 26-08-2005 PP-00020 EMENT VOL-02202-12 PP-02560) (Grifo nosso.)
} 
clássica dupla conveniência e oportunidade, optaria pelo melhor momento de convocar os candidatos regularmente aprovados.

Apenas se falaria em direito subjetivo à nomeação se houvesse preterição na ordem de classificação, conforme leciona a Súmula $n^{0} 15$ do STF aprovada em 13 de dezembro de 1963. Segue transcrição:

Dentro do prazo de validade do concurso, o candidato aprovado tem o direito à nomeação, quando o cargo fôr preenchido sem observância da classificação.

O entendimento tradicional, de que somente a mera expectativa de direito era devida aos aprovados no concurso dentro do número de vagas prevista no edital, perdurou durante vários anos, preservando-se até mesmo alguns décadas depois da promulgação da Carta Cidadã como pode ser visto através do entendimento do STF no RMS 22063$\mathrm{RJ}^{24}$, relatado pelo Ministro Marco Aurélio em 1995 (DJ 07/12/1995):

RECURSO EM MANDADO DE SEGURANÇA. ADVOGADO-DE-OFÍCIO SUBSTITUTO DA JUSTIÇA MILITAR: NÃO PROVIMENTO DOS CARGOS POR ATO DA ADMINISTRAÇÃO; DESNECESSIDADE DE PROVIMENTO DOS CARGOS VAGOS PARA OS QUAIS FOI REALIZADO CONCURSO PÚBLICO DE PROVAS E TÍTULOS. ENTENDIMENTO DA SÚMULA N $^{\circ} 15$ DO STF. INDENIZAÇÃO POR FALTA DE NOMEAÇÃO.

1- A doutrina e a jurisprudência têm-se orientado no sentido da discricionariedade quanto à oportunidade e conveniência de prover os cargos públicos. I- Não vicia a legalidade e a legitimidade o ato administrativo que, fundamentado na inexistência de necessidade, decide não prover os cargos vagos. IIA simples convocação, sem motivo explicitado, de candidato classificado em situação inferior não significa certeza de nomeação nem demonstra interesse da Administração em preencher as vagas

\footnotetext{
${ }^{24}$ BRASIL. Supremo Tribunal Federal. RMS: 22063 RJ, Relator: Min. MARCO AURÉLIO, Data de Julgamento: 26/06/1995, Segunda Turma, Data de Publicação: DJ 07-12 1995 PP-42608 EMENT VOL-01812-01 PP-00106

${ }^{25}$ BRASIL. Supremo Tribunal Federal. Recurso. Extraordinário. Inadmissibilidade. Concurso Público. Nomeação. Ordem de classificação. Observância. Preterição. Inexistência.
}

existentes, não gerando direito ao provimento do cargo.

2- Na interpretação da Súmula $n^{\circ} 15$, desta Corte, o que se assegura ao concursado habilitado é o direito à nomeação, no prazo de validade do concurso, quando ele é preterido por candidato em situação inferior na ordem de classificação dos aprovados.

3- A norma constitucional ínsita no art. 37, § $6^{\circ}$, refere-se à responsabilidade civil do Estado por danos causados a terceiros na prestação de serviços públicos, não ensejando qualquer indenização ao candidato habilitado em concurso público mas não nomeado por interesse da Administração.

4- Recurso ordinário improvido. (Grifo nosso.)

Até décadas depois da promulgação da Carta Cidadã, quando já se tinham estudos mais maduros na área do Direito Administrativo, o STF manteve sua posição tradicional conforme se vê no julgado $^{25}$ de 2007, publicado no DJ em 11/10/2007:

RECURSO. Extraordinário. Inadmissibilidade. Concurso Público. Nomeação. Ordem de classificação. Observância. Preterição. Inexistência. Aplicação da súmula 15.

A aprovação em concurso público não gera, em princípio, direito à nomeação, constituindo mera expectativa de direito. Esse direito surgirá se houver o preenchimento de vaga sem observância de ordem classificatória.

Diante desses julgados, fica comprovado que o entendimento dominante não garantia ao candidato aprovado e classificado, com exceção da situação prevista na Súmula 15, o direito subjetivo à nomeação em regra.

Deixava-se, pois, a cargo da esfera administrativa o poder de decidir quantos iria nomear ou até mesmo se iria nomear alguém.

Esse tipo de liberdade ofereceu margem para que a própria Administração Pública pudesse desvirtuar o instituto do concurso público, pois se abriu a possibilidade para casos em que, mesmo

Aplicação da súmula 15. Recurso Extraordinário n ${ }^{\circ} 306.938$ AgR, Relator(a): Min. Cezar Peluso, Segunda Turma, julgado em 18 de setembro de 2007. DJe-121 Divulgado em 10 de outubro de 2007. Publicado em 11 de outubro de 2007. 
diante de candidatos aprovados dentro do número de vagas previsto no edital, nomeavam-se um número inferior ao divulgado ou não se nomeava.

Como o Judiciário não concedia o direito subjetivo à nomeação para os aprovados e classificados em concurso, o órgão público figurava numa posição de bastante conforto, pois poderia publicar edital e, depois, não precisava se comprometer com a contratação de nenhum candidato.

Na verdade, além de não precisar dispender receita nomeando os aprovados, gerava-se, na verdade, receita, isto é, lucro para o próprio órgão através dos valores das inscrições e até certo proveito político pela gestão ter realizado concurso público $^{26}$ - fato que sempre toma lugar na mídia devido ao grande interesse da população em ocupar cargos e empregos públicos efetivos.

Somente em 2011, o STF mudou de posição e evoluiu de forma acertada o seu entendimento sobre o direito subjetivo à nomeação no Recurso Extraordinário 598.099/MS com Repercussão Geral reconhecida cuja relatoria se deu pelo Ministro Gilmar Mendes, DJe 03/10/2011. Tal decisão se mostrou importante, pois forneceu maior segurança jurídica aos candidatos aprovados, além de impor planejamento por parte da Administração na quantidade de vagas ofertadas.

Ficou, então, pacificada a tese de que o candidato aprovado dentro do número de vagas previsto no edital do concurso público possui direito subjetivo à nomeação. Salvo em casos excepcionais, surge um dever da Administração Pública de nomear, nascendo um direito subjetivo no lugar de mera expectativa de direito.

Seguem os principais trechos da ementa ${ }^{27}$ que abarca pontos importantes dessa virada jurisprudencial tão significativa para os estudos acadêmicos sobre concurso público:
RECURSO EXTRAORDINÁRIO. REPERCUSSÃO GERAL. CONCURSO PÚBLICO. PREVISÃO DE VAGAS EM EDITAL. DIREITO À NOMEAÇÃO DOS CANDIDATOS APROVADOS.

I. DIREITO À NOMEAÇÃO. CANDIDATO APROVADO DENTRO DO NÚMERO DE VAGAS PREVISTAS NO EDITAL. Dentro do prazo de validade do concurso, a Administração poderá escolher o momento no qual se realizará a nomeação, mas não poderá dispor sobre a própria nomeação, a qual, de acordo com o edital, passa a constituir um direito do concursando aprovado e, dessa forma, um dever imposto ao poder público. Uma vez publicado o edital do concurso com número específico de vagas, o ato da Administração que declara os candidatos aprovados no certame cria um dever de nomeação para a própria Administração e, portanto, um direito à nomeação titularizado pelo candidato aprovado dentro desse número de vagas.

II. ADMINISTRAÇ̃̃O PÚBLICA. PRINCÍPIO DA SEGURANÇA JURÍDICA. BOA-FÉ. PROTEÇÃO À CONFIANÇA. O dever de boa-fé da Administração Pública exige o respeito incondicional às regras do edital, inclusive quanto à previsão das vagas do concurso público. Isso igualmente decorre de um necessário e incondicional respeito à segurança jurídica como princípio do Estado de Direito. $[\ldots]$

\section{SITUAÇÕES EXCEPCIONAIS.} NECESSIDADE DE MOTIVAÇÃO. CONTROLE PELO PODER JUDICIÁRIO. Quando se afirma que a Administração Pública tem a obrigação de nomear os aprovados dentro do número de vagas previsto no edital, deve-se levar em consideração a possibilidade de situações excepcionalíssimas que justifiquem soluções diferenciadas, devidamente motivadas de acordo com o interesse público. [...] Para justificar o excepcionalíssimo não cumprimento do dever de nomeação por parte da Administração Pública, é necessário que a situação justificadora seja dotada das seguintes características: a) Superveniência, [...]; b) Imprevisibilidade $[\ldots]$; c) Gravidade $[\ldots]$; d) Necessidade [...]. De toda forma, a recusa de nomear candidato aprovado dentro do número de vagas deve ser devidamente motivada e, dessa forma, passível de controle pelo Poder Judiciário. [...]

V. NEGADO PROVIMENTO AO RECURSO EXTRAORDINÁRIO. (Grifo nosso.)

\footnotetext{
${ }^{26}$ FORTINI, Cristiana; MOTTA, Fabricio. Concurso Público e Direito à Nomeação. In: PEREIRA, Flávio Henrique Unes et al (Coord.). O direito administrativo na jurisprudência do STF e do STJ: Homenagem ao Professor Celso Antônio. Belo Horizonte: Fórum, 2014. p. 130.
}

${ }^{27}$ BRASIL. Supremo Tribunal Federal. RE: 598099 MS, Relator: Min. GILMAR MENDES, Data de Julgamento: 10/08/2011, Tribunal Pleno, DJe-189, Data de Divulgação: 30-09-2011, Data de Publicação: 03-10-2011. REPERCUSSÃO GERAL - MÉRITO. 
O fato de a Administração publicar um edital de concurso público representa intensão e necessidade de preencher certos cargos públicos. Todo o conjunto de planejamento que envolve esse tipo de certame representa - ou pelo menos deveria - uma possibilidade concreta e real de se obter mão de obra para o órgão que demonstrou interesse em realiza-lo.

Vê-se que o julgado trouxe uma tendência que a doutrina já expunha há algum tempo, isto é, da relevância de se considerarem os princípios da segurança jurídica com a sua vertente subjetiva que protege a boa-fé confiada pela população na própria Administração Pública.

Luciano Ferraz ${ }^{28}$, já em 2005, argumentou que há uma grande responsabilidade do órgão que publica um edital para prover a contratação de pessoas. Assim, seria, no mínimo, imprescindível a explicitação de motivos que sejam razoavelmente aceitáveis caso as nomeações não ocorram já que, na sua visão, os aprovados dentro do número das vagas previstas possuem direito subjetivo à nomeação.

Ele, ainda, vai além quando leciona que caso a Administração deixe claro através da publicação de um edital, ou de atos de desvio de poder, como contratações temporárias e terceirização de serviços, que precisa de mão de obra dos aprovados ou, ainda, caso surjam novas vagas durante o prazo do concurso, haveria uma mudança de mera expectativa de direito para direito subjetivo ${ }^{29}$.

Nesse contexto, importante registrar que a jurisprudência do STJ, também, evoluiu se mostrando atenta aos avanços doutrinários existentes e ao entendimento do STF conforme exposto.

Assim, o STJ reconhece que existe direito adquirido à nomeação dos candidatos aprovados

\footnotetext{
${ }^{28}$ FERRAZ, Luciano. Concurso público e direito à nomeação. In: MOTTA, Fabrício (Coord.). Concurso Público e Constituição. Belo Horizonte: Fórum, 2005. p. 255.

${ }^{29}$ FERRAZ, Luciano, op. cit. p. 255.

30 BRASIL. Superior Tribunal de Justiça. RMS $n^{\circ}$ 23331/RO. Relator: Ministra Maria Thereza de Assis Moura. Brasília, DF, 16 de março de 2010. DJe. Brasília, 05 abr. 2010.
}

em concurso público, para as vagas oferecidas durante a validade determinada pelo edital do concurso. Veja-se ${ }^{30}$.

RECURSO ORDINÁRIO. MANDADO DE SEGURANÇA. CONCURSO PÚBLICO. APROVAÇÃO DENTRO DO NÚMERO DE VAGAS PREVISTO NO EDITAL. DIREITO SUBJETIVO À NOMEAÇÃO. PRECEDENTES.

1. De acordo com entendimento consolidado deste Superior Tribunal de Justiça, o candidato aprovado dentro do número de vagas previsto no edital do certame não tem mera expectativa de direito, mas verdadeiro direito subjetivo à nomeação para o cargo a que concorreu e foi classificado. Precedentes.

2. Recurso ordinário provido. (Grifo nosso.)

Por fim, faz-se necessário esclarecer que, diante da evolução aqui apresentada, ainda se encontra previsto à Administração Pública a escolha do melhor momento para se realizar a nomeação de seus candidatos aprovados, desde que o faça dentro da validade estabelecida no edital do certame.

Outro ponto a ser iluminado é que esses entendimentos não vincularam o órgão público sempre a nomear seus candidatos aprovados. Evidentemente, no caso de alguma situação justificável e devidamente motivada, que possui as características da superveniência, imprevisibilidade, gravidade e da necessidade, há possibilidade de se não nomear. Entretanto, isso é a exceção ${ }^{31}$.

Percebe-se, portanto, que a doutrina junto com os Tribunais superiores buscaram organizar e, acima de tudo, fornecer segurança jurídica aos candidatos que se dedicam à realização de concursos públicos, porém sem engessar nem transpor a atuação da Administração Pública.

${ }^{31}$ O STF já julgou uma suspensão de segurança em que o Ministro Ricardo Lewandowski deferiu o pedido para suspender a segurança concedida a candidatos aprovados dentro do número de vagas num concurso público, pois a lei que estatual que criou unidade de serviço público era inconstitucional. 


\section{TUTELA DO DIREITO À NOMEAÇÃO DE CANDIDATO APROVADO EM CONCURSO PÚBLICO NO CADASTRO DE RESERVA: O CASO DO RECURSO EXTRAORDINÁRIO 837.311/PI}

O concurso público, como meio de acesso a cargos e empregos públicos, se apresenta como um instrumento concretizador da democracia, selecionando candidatos de forma republicana e impessoal.

Ele garante o respeito aos princípios da Administração Pública expostos no art. 37, caput da Constituição Federal de 1988, além de outros tantos sejam explícitos, como o da isonomia previsto no art. $5^{\circ}$, caput, CRFB/88, ou implícitos como o da boa-fé e da proteção à confiança.

A sua efetivação ocorre por meio de um processo administrativo em que o Estado procura, naquele momento, o candidato melhor preparado segundo as regras do edital, privilegiando-se o princípio constitucional da eficiência.

O certame deve, ainda, garantir de forma ampla, democrática e impessoal o acesso aos cargos e empregos estatais durante as fases editalícias, identificando os mais capazes por meio de critérios objetivos.

Tais características inerentes a todo concurso público garantem - ao menos em tese - o aniquilamento de qualquer tipo de privilégio ou favoritismo, como também impede qualquer tipo de tratamento discriminatório ou arbitrário.

Nesse sentido, as lições de Joaquim José Gomes Canotilho e de Vital Moreira ${ }^{32}$ se aplicam neste momento para fortalecer as discussões sobre o instituto em tela:

A regra constitucional do concurso consubstancia um verdadeiro direito a um procedimento justo de recrutamento, vinculado aos princípios constitucionais e legais (igualdade de condições e oportunidades para todos os candidatos, liberdade das candidaturas, divulgação atempada dos métodos e provas de selecção, bem como dos respectivos programas e sistemas de classificação, aplicação de métodos e critérios objectivos de avaliação, neutralidade na composição do júri, direito de recurso). $\mathrm{O}$ concurso assente num procedimento justo é também uma forma de recrutamento baseado no mérito, pois o concurso serve para comprovar competências.

$\mathrm{Na}$ mudança de paradigma proferida pelo Ministro Gilmar Mendes no RE 598.099/MS com ementa já transcrita neste trabalho - ele leciona de forma pertinente que o dever da boa-fé da Administração Pública obriga que se haja respeito completo às regras do edital, incluindo o quantitativo de vagas previstos.

Isso se justificaria, ainda segundo o Ministro, devido à necessidade completa de se respeitar a segurança jurídica como princípio do Estado de Direito. Haveria, portanto, um depósito de confiança no Estado administrador de todos aqueles que se submetem à realização do certame. Assim, um comportamento estatal responsável e que tenha como baliza o princípio da segurança jurídica é o mínimo esperado pelo depositante, pautando-se sempre pela boa fé objetiva e subjetiva.

Conforme já mencionado, a abertura de um processo seletivo para obtenção de mão de obra demonstra clara necessidade e intenção de preenchimentos de determinados cargos ou empregos públicos.

Começa-se, nesse momento, todo um investimento emocional, físico, temporal e financeiro dos candidatos para que possam realizar as fases do exame. Incontáveis horas são dispendidas e inúmeras renúncias são feitas pelos pretendentes, a fim de se obter a almejada vaga.

Assim, como a Administração se submete, invariavelmente, às próprias regras do edital, o planejamento prévio certamente é feito, para que haja

\footnotetext{
32 CANOTILHO, Joaquim José Gomes; MOREIRA, Vital. Constituição da República Portuguesa anotada. v. 1. São Paulo: Revista dos Tribunais, 2007. p. 661.
} 
uma coerência entre a necessidade do órgão e o número de vagas previstas no instrumento convocatório.

A fim de maximizar a eficiência do certame, além de permitir economicidade e celeridade no provimento de cargos, existe a figura do cadastro de reserva.

Essa categoria se caracteriza quando o candidato foi aprovado segundo as regras do edital, porém restou numa classificação maior que a prevista no número de vagas previamente disponibilizadas. Nada mais é que um instrumento de planejamento do Estado que busca atender o interesse público.

Como o Administrador do órgão necessitante de mão de obra não pode prever com precisão, durante toda a validade do concurso, quantas vagas restarão vagas e quantas pessoas serão necessárias para o seu órgão, o cadastro de reserva se mostra uma ferramenta bastante eficiente para realizar um aproveitamento rápido e eficaz daqueles já aprovados sem abertura de novo concurso.

Segundo visto na parte de evolução jurisprudencial sobre nomeação, os aprovados dentro do número de vagas previsto possuem direito subjetivo à nomeação, podendo a Administração Pública fazê-lo a qualquer momento durante a validade do concurso.

Já os aprovados em cadastro de reserva possuem mera expectativa de direito, ficando a espera da necessidade Estatal e do surgimento de vagas para que sejam nomeados.

Existem, entretanto, alguns casos em que os aprovados em cadastro de reserva, que antes só detinham uma mera expectativa de serem nomeados, passam a ter direito subjetivo à nomeação.

Isso, geralmente, acontece quando a Administração realiza alguma ação ou demonstração

\footnotetext{
${ }^{33}$ Como exemplo podemos citar a jurisprudência do Supremo Tribunal Federal. RE 598.099/MS, Repercussão Geral - Mérito, Tribunal do Pleno, Rel. Ministro Gilmar Mendes, julgamento em 10.08.2011 e as do Superior Tribunal de
}

inequívoca de que necessita de mão de obra e está se valendo de outros artifícios para consegui-la.

$\mathrm{O}$ caso a ser analisado aqui para melhor ilustrar uma dessas situações é quando o Estado abre novo edital, embora já há uma lista de aprovados para o mesmo cargo realizado em certame anterior e com validade em vigor.

Importante rememorar que o entendimento jurisprudencial $^{33}$ atual afirma que a mera abertura de novas vagas durante a validade do concurso não gera, automaticamente, o direito subjetivo à nomeação dos candidatos aprovados em cadastro de reserva, ainda que tenha ocorrido durante a validade de outro concurso para o mesmo cargo.

O provimento dos cargos, como já se lecionou, está sujeito à análise discricionária da Administração Pública, baseando-se no binômio conveniência e oportunidade.

A impossibilidade imediata de surgir direito subjetivo à nomeação devido ao nascimento de novas vagas acontece pela possibilidade de haver razões e circunstâncias legítimas de interesse público que respaldem a impossibilidade de nomeação em curto prazo. Pode ocorrer, por exemplo, que o órgão não esteja de imediato preparado financeiramente para realizar a contratação de mão de obra em número acima do previsto no primeiro edital.

Se o surgimento de novas vagas desse um direito subjetivo automático aos candidatos aprovados em cadastro de reserva, isso fulminaria a atuação discricionária do Administrador Público, pois ele teria sempre que esperar a validade do outro concurso, mesmo que planejasse nomear os novos aprovados em tempo futuro.

A fim de exemplificar, percebe-se que um Administrador deseja realizar concurso para prover vagas para um determinado cargo, porém há outro concurso válido com candidatos aprovados

Justiça, quais sejam AgRg no RMS 26947/CE, Rel. Min. Felix Fischer; EDcl no REsp 824299/RS, Rel. Min. Arnaldo Esteves Lima, DJe de 2.6.2008. No mesmo sentido, ainda, o AgRg no AgRg no REsp 778118, $5^{\text {a }}$ Turma, Rel. Min. Jorge Mussi, DJe de 15.02.2013. 
em cadastro de reserva. $\mathrm{O}$ gestor pode querer realizar novo certame para escolher, novamente, os melhores preparados para exercer aquele cargo. Perceba que se houvesse um direito subjetivo automático, ele ficaria engessado e não poderia decidir se preferiria nomear os últimos colocados do concurso em vigência ou novos e, talvez, melhores candidatos.

Porém, se a Administração realiza ações que, propositalmente, objetivem o fim da validade, de modo desnecessário e até reprovável, do concurso para se evitar as nomeações dos aprovados no concurso anterior, tem-se outra situação.

Caso a necessidade de preenchimento da vaga seja imediata com a abertura de novo concurso e, ainda, existam candidatos aprovados fora das vagas do certame antigo ainda válido, haverá uma vinculação do princípio da boa-fé com a discricionariedade da Administração, impondo-lhe o preenchimento das vagas com os candidatos já $\operatorname{aprovados}^{34}$.

São nessas situações que, conforme leciona o Ministro Fux, a atuação discricionária da Administração em relação à melhor oportunidade de nomeação fica reduzida a um patamar tão pequeno, que resta quase nulo. Esse fenômeno é apontado pela doutrina alemã como "redução da discricionariedade a zero" (Ermessensreduzierung auf $N u l l)^{35}$.

A jurisprudência, então, só entende que há um direito subjetivo à nomeação dos aprovados no cadastro de reserva em caso excepcional como o que foi aqui discutido.

O gestor, dessa forma, detém a possibilidade de avaliar se preferirá os piores colocados de um concurso válido ou os melhores aprovados de um processo seletivo. Caso opte pela segunda opção,

\footnotetext{
${ }^{34}$ BRASIL. Supremo Tribunal Federal. Acórdão $n^{\circ}$ RE 837311/PI. Relator: Ministro Luiz Fux. DJe. Brasília, 18 abr. 2016. p. 14.

35 HUFEN, Christian. Ermessen und unbestimmter Rechtsbegriff. 2010, 603. Disponível em: <http://www.zjs-online.com/dat/artikel/20105373.pdf>. p. 605 apud BRASIL.
}

há de se ter o cuidado de se programar para as nomeações do novo concurso ocorrem após o fim da validade do primeiro.

Havendo atuação de má-fé do administrador público ao, intencionalmente, deixar findar o prazo de validade para favorecer, indevidamente, os candidatos aprovados no novo certame, nasce o direito subjetivo à nomeação dos candidatos da primeira seleção.

A própria Constituição garante a preferência aos candidatos aprovados em concurso prévio no seu inciso IV do art. 37:

IV - durante o prazo improrrogável previsto no edital de convocação, aquele aprovado em concurso público de provas ou de provas e títulos será convocado com prioridade sobre novos concursados para assumir cargo ou emprego, na carreira;

Nesse mesmo sentido, tem-se Celso Antônio Bandeira de Mello ${ }^{36}$ :

Os concursos públicos terão validade de até dois anos, prorrogáveis uma vez por igual período (art. 37, III), isto é, por tempo igual ao que lhes haja sido originariamente consignado (art. 37, IV). No interior de tal prazo os aprovados terão precedência para nomeação sobre novos concursados (art. 37, IV). Como consequência desta prioridade, a Administração só com eles poderá preencher as vagas existentes dentro de seu periodo de validade, que já existissem quando da abertura do certame, quer ocorridas depois. É certo, outrossim, que não poderá deixá-lo escoar simplesmente como meio de se evadir ao comando de tal regra nomeando em seguida os aprovados no concurso sucessivo, que isto seria um desvio de poder. Com efeito, se fosse possível agir deste modo, a garantia do inciso IV não valeria nada, sendo o mesmo uma letra morta". (Grifo nosso.)

O próprio $\mathrm{STF}^{37}$, em 2011, teve a oportunidade de se manifestar sobre o assunto, corroborando com os argumentos aqui trazidos:

Supremo Tribunal Federal. Acórdão no RE 837.311/PI. Relator: Ministro Luiz Fux. DJe. Brasília, 18 abr. 2016, p. 14. ${ }^{36}$ MELLO, Celso Antônio Bandeira de. Curso de Direito Administrativo. 30. ed. São Paulo: Malheiros, 2013; p. 288. ${ }^{37}$ BRASIL. Supremo Tribunal Federal. MS 24660, Relatora Min. Ellen Gracie, Relatora p/ Acórdão Min. Cármen Lúcia, Tribunal Pleno, DJe 23-09-2011. 
Por fim, apresenta-se um caso concreto ana-

nos termos constitucionalmente postos, não inibe a abertura de novo concurso a existência de candidatos classificados em evento ocorrido antes. O que não se permite, no entanto, no sistema vigente, é que, durante o prazo de validade do primeiro, os candidatos classificados para os cargos na seleção anterior sejam preteridos por aprovados em novo certame.

Agir de forma diversa seria ferir gravemente os princípios da impessoalidade, eficiência, moralidade e da proteção à confiança.

Este último é, inclusive, essencial para fornecer uma margem estável de segurança jurídica aos administrados, a fim de que suas expectativas não sejam frustradas pela má-fé do Estado.

Nesse contexto, Canotilho ${ }^{38}$ leciona que:

O homem necessita de segurança para conduzir, planificar e conformar autônoma e responsavelmente sua vida. Por isso, desde cedo se consideraram os princípios da segurança jurídica e da protecção da confiança como elementos constitutivos do Estado de direto.

O Estado possui, pois, a obrigação de demonstrar ao cidadão de que suas ações são válidas, constitucionais e estão em total consonância com o ordenamento jurídico.

Ao se publicar um edital de concurso, que convoca irrestritamente todos aqueles que se interessarem e puderem realizar o certame para o preenchimento de vagas, há o nascimento de uma expectativa de que as regras ali postas no edital e as já existentes no ordenamento jurídico, que tenham relação com o concurso, sejam respeitadas.

Os candidatos aprovados, portanto, realizam um depósito de confiança no Estado administrador e espera que este atue de forma responsável desde a publicação do edital até às nomeações para provimento efetivo das vagas. lisando, recentemente, pelo STF que ilustra bem o contexto deste artigo.

O Recurso Extraordinário 837.311 - com repercussão geral - originário do Piauí, com acórdão publicado em 18 de abril de 2016, versa sobre o resultado de concurso público para Defensor Público do estado do Piauí que foi homologado em 24 de março de 2004, com prazo de validade de dois anos, tendo sido o certame prorrogado por igual período.

Os aprovados no certame, tendo alcançado a média final exigida, impetraram um Mandado de Segurança, apesar de terem ficado na classificação final, além do número de vagas previstas no Edital.

Ocorreu que, tempo depois, mas, ainda, dentro da validade do mencionado concurso, o Estado manifestou inequívoco interesse, havendo, inclusive, a previsão orçamentária para tanto, de realizar novo concurso para o mesmo cargo.

Ficou constatado, ainda, que, menos de seis meses após o término da validade do concurso em tela, a própria Defensoria Pública do Estado do Piauí reconheceu, expressamente, que deveriam ser nomeados 40 defensores.

Assim, conforme comenta o Ministro Relator Luiz Fux ${ }^{39}$, a instituição não poderia, portanto, ter deixado escoar o prazo do concurso sem nomear os aprovados no cadastro de reserva, especialmente frente ao reconhecimento, em reunião entre os representantes da Defensoria Pública e o Governador do Estado do Piauí ocorrida em 2007, de que a regionalização da Defensoria justificaria a referida nomeação conforme consta nos autos processuais.

Tem-se, portanto, uma situação singular, isto é, extraordinária, em que a instituição, no caso concreto, reduziu a sua discricionariedade a pata-
${ }^{38}$ CANOTILHO, José Joaquim Gomes. Direito Constitucional e Teoria da Constituição. $7^{\mathrm{a}}$ Edição, Coimbra - Portugal: Ed. Almedina, 2000. p. 257.
39 BRASIL. Supremo Tribunal Federal. Acórdão $\mathrm{n}^{\mathbf{o}} \mathrm{RE}$ 837.311/PI. Relator: Ministro Luiz Fux. DJe. Brasília, 18 abr. 2016. p. 25. 
mares baixos, autolimitando-se na discricionariedade quanto ao melhor momento para nomear os seus defensores públicos.

Diante dos argumentos aqui apresentados para esse caso, o Ministro, então, negou provimento ao Recurso Extraordinário ${ }^{40}$, que foi ajuizado pelo Estado do Piaú, sob os argumentos da clara necessidade de novos defensores públicos para o estado, dos princípios da eficiência, da boafé, da moralidade, da impessoalidade e da proteção à confiança.

${ }^{40}$ EMENTA: RECURSO EXTRAORDINÁRIO. CONSTITUCIONAL E ADMINISTRATIVO. REPERCUSSÃO GERAL RECONHECIDA. TEMA 784 DO PLENÁRIO VIRTUAL. CONTROVÉRSIA SOBRE O DIREITO SUBJETIVO À NOMEAÇÃO DE CANDIDATOS APROVADOS ALÉM DO NÚMERO DE VAGAS PREVISTAS NO EDITAL DE CONCURSO PÚBLICO NO CASO DE SURGIMENTO DE NOVAS VAGAS DURANTE O PRAZO DE VALIDADE DO CERTAME. MERA EXPECTATIVA DE DIREITO À NOMEAÇÃO. ADMINISTRAÇÃO PÚBLICA. SITUAÇÕES EXCEPCIONAIS. IN CASU, A ABERTURA DE NOVO CONCURSO PÚBLICO FOI ACOMPANHADA DA DEMONSTRAÇÃO INEQUÍVOCA DA NECESSIDADE PREMENTE E INADIÁVEL DE PROVIMENTO DOS CARGOS. INTERPRETAÇÃO DO ART. 37, IV, DA CONSTITUIÇÃO DA REPÚBLICA DE 1988. ARBÍTRIO. PRETERIÇÃOO CONVOLAÇÃO EXCEPCIONAL DA MERA EXPECTATIVA EM DIREITO SUBJETIVO À NOMEAÇÃO. PRINCÍPIOS DA EFICIÊNCIA, BOA-FÉ, MORALIDADE, IMPESSOALIDADE E DA PROTEÇÃO DA CONFIANÇA. FORÇA NORMATIVA DO CONCURSO PÚBLICO. INTERESSE DA SOCIEDADE. RESPEITO À ORDEM DE APROVAÇÃO. ACÓRDÃO RECORRIDO EM SINTONIA COM A TESE ORA DELIMITADA. RECURSO EXTRAORDINÁRIO A QUE SE NEGA PROVIMENTO. [...].

2. O edital do concurso com número específico de vagas, uma vez publicado, faz exsurgir um dever de nomeação para a própria Administração e um direito à nomeação titularizado pelo candidato aprovado dentro desse número de vagas. Precedente do Plenário: RE 598.099 - RG, Relator Min. Gilmar Mendes, Tribunal Pleno, DJe 03-10-2011.

3. O Estado Democrático de Direito republicano impõe à Administração Pública que exerça sua discricionariedade entrincheirada não, apenas, pela sua avaliação unilateral a respeito da conveniência e oportunidade de um ato, mas, sobretudo, pelos direitos fundamentais e demais normas constitucionais em um ambiente de perene diálogo com a sociedade. [...].
O julgamento desse caso se mostrou importante, pois existem entendimentos divergentes recentes sobre a matéria de nomeação sobre aprovados em cadastro de reserva no STF.

Em 2014, a Primeira Turma do referido Tribunal, em 2014, concluiu, num Agravo Regimental no RE 757.978 relatado pelo Ministro Luiz $\mathrm{Fux}^{41}$, que o surgimento de novas vagas durante o prazo de validade de concurso não faz nascer, de forma automática, direito à nomeação dos candidatos aprovados fora das vagas do edital.
7. A tese objetiva assentada em sede desta repercussão geral é a de que o surgimento de novas vagas ou a abertura de novo concurso para o mesmo cargo, durante o prazo de validade do certame anterior, não gera automaticamente o direito à nomeação dos candidatos aprovados fora das vagas previstas no edital, ressalvadas as hipóteses de preterição arbitrária e imotivada por parte da administração, caracterizadas por comportamento tácito ou expresso do Poder Público capaz de revelar a inequívoca necessidade de nomeação do aprovado durante o período de validade do certame, a ser demonstrada de forma cabal pelo candidato. Assim, a discricionariedade da Administração quanto à convocação de aprovados em concurso público fica reduzida ao patamar zero (Ermessensreduzierung auf Null), fazendo exsurgir o direito subjetivo à nomeação, verbi gratia, nas seguintes hipóteses excepcionais: i) Quando a aprovação ocorrer dentro do número de vagas dentro do edital (RE 598.099); ii) Quando houver preterição na nomeação por não observância da ordem de classificação (Súmula 15 do STF); iii) Quando surgirem novas vagas, ou for aberto novo concurso durante a validade do certame anterior, e ocorrer a preterição de candidatos aprovados fora das vagas de forma arbitrária e imotivada por parte da administração nos termos acima.

8. In casu, reconhece-se, excepcionalmente, o direito subjetivo à nomeação aos candidatos devidamente aprovados no concurso público, pois houve, dentro da validade do processo seletivo e, também, logo após expirado o referido prazo, manifestações inequívocas da Administração piauiense acerca da existência de vagas e, sobretudo, da necessidade de chamamento de novos Defensores Públicos para o Estado. [...] (Grifo nosso.)

BRASIL. Supremo Tribunal Federal. RE: 837311 PI, Relator(a): Min. LUIZ FUX, Tribunal Pleno, Data de Julgamento: 09/12/2015, PROCESSO ELETRÔNICO REPERCUSSÃO GERAL - MÉRITO DJe-072 Data de Divulgação: 15-04-2016, Data de Publicação 18-04-2016.

${ }^{41}$ BRASIL. Supremo Tribunal Federal. STF - ARE: 757978 MG, Relator: Min. LUIZ FUX, Data de Julgamento: 25/02/2014, Primeira Turma, Data de Publicação: DJe-068 DIVULG 04-04-2014 PUBLIC 07-04-2014. 
Por outro lado, a Segunda Turma do mesmo Tribunal, em outro Agravo Regimental em Recurso Extraordinário 790.897 relatado pelo Ministro Ricardo Lewandowski ${ }^{42}$, também em 2014, assentou que o direito de nomeação, também, se estenderia ao candidato aprovado no cadastro de reserva desde que surgissem novas vagas no prazo de validade do concurso.

A Administração Pública deve possuir, pois, responsabilidade e planejamento no campo da nomeação de aprovados em concurso público, a fim de não ferir os princípios e demais normas citados do ordenamento jurídico brasileiro em nome da liberdade de atuação conferida pelo poder discricionário.

O delineamento no RE em tela permitiu, portanto, o fim de uma discussão importante sobre o tema nomeação em concurso público, gerando segurança jurídica aos jurisdicionados e fortalecendo o instituto constitucional do concurso público.

\section{CONCLUSÃO}

A nomeação de aprovados em concurso público para cargos ou empregos é de cunho discricionário. Assim, o gestor possui a liberdade de escolher o melhor momento para fazê-lo, levando em conta o binômio conveniência e oportunidade, desde que respeite os limites da lei, o critério de razoabilidade e os direitos fundamentais dos administrados.

Viu-se que, apesar de haver esse espaço de liberdade, ele não pode ser arbitrário, caso contrário estará viciado e será considerado ilegal, deixando de surtir efeitos no mundo jurídico.

Dessa forma, quando há atitudes arbitrárias da Administração Pública na metodologia da nomeação dos candidatos que lograram êxito, é possível impor freio à discricionariedade administrativa.
Isso ocorre devido à lei e ao Direito, pois todo ato deve-se pautar em respeito ao princípio da juridicidade, que, de forma ampla, compreende não só as normas positivadas, mas também todo o conjunto que forma o ordenamento jurídico.

Perante casos irregulares e diante do princípio da inafastabilidade do controle jurisdicional, o Poder Judiciário não pode se esquivar de analisar tais atos praticados no exercício da competência discricionária.

Atualmente, firma-se, pacificamente, nos Tribunais superiores que o aprovado dentro do número de vagas previsto no edital possui direito subjetivo à nomeação dentro do período de validade do concurso. Já os aprovados no cadastro de reserva possuem apenas mera expectativa de direito.

Entretanto, a mera expectativa pode se tornar direito subjetivo, quando a Administração Pública fere os princípios da segurança jurídica, da proteção à confiança depositada pelos administrados e da boa-fé objetiva.

Quando isso ocorre, está-se diante de uma situação limitadora da discricionariedade conferida ao poder público na nomeação, pois acontece o fenômeno alemão "redução da discricionariedade a zero" (Ermessensreduzierung auf Null). Logo, a atuação discricionária ficaria tão reduzida que se alcançaria um patamar quase nulo.

Foi, pois, o que ocorreu no caso analisado no Recurso Extraordinário 837.311/PI - com repercussão geral - relatado pelo Ministro Luiz Fux. Mostrou-se, que a mera abertura de novo concurso para o mesmo cargo, não geraria direito subjetivo à nomeação, porém como houve sinalização inequívoca da necessidade imediata de se nomear mais defensores para atuar no Estado com outro concurso válido, quebrou-se a proteção à confiança dos candidatos aprovados e não nomeados do primeiro exame.

${ }^{42}$ BRASIL. Supremo Tribunal Federal. STF-ARE: 790.897 Julgamento: 25/02/2014 , Segunda Turma, DJe-045 DIRJ, Relator: Min. RICARDO LEWANDOWSKI, Data de VULG 06-03-2017 PUBLIC 07-03-2014. 
Assim, diante de uma atuação dessa monta, controle jurisdicional e à necessidade da atuação que feriu não só o princípio citado, mas também os administrativa estar sempre baseada no princípios da eficiência, impessoalidade, ordenamento jurídico mesmo quando haja uma economicidade e da boa-fé, o poder de atuação margem para atuação criativa do gestor, é possível discricionária foi reduzido bruscamente, gerando, legalmente e faticamente reduzir o campo de então, o surgimento do direito subjetivo à atuação discricionária do Administrador Público, nomeação no lugar de uma mera expectativa de gerando direito subjetivo a seus administrados direito. quando, de forma inequívoca, se fere princípios

Conclui-se, portanto, que, devido ao basilares do Direito, em especial, os aqui citados. princípio da princípio da inafastabilidade do

\section{REFERÊNCIAS}

BRASIL. Constituição (1988). Planalto, Brasília. Disponível em: <http://www.planalto.gov.br/ccivil_03/constituicao/constituicaocompilado.htm>. Acesso em: 02 jul. 2017. Não paginado.

. Superior Tribunal de Justiça. RMS 20.481 / MT, Relator Ministro Gilson Dipp, julgamento no dia 17/08/2006, Órgão julgador a quinta turma - T5, publicado no Diário de Justiça do dia 11/09/2006, na página 316.

. Superior Tribunal de Justiça. RMS no 23.331/RO. Relatora: Ministra Maria Thereza de Assis Moura. Brasília, DF, 16 de março de 2010. DJe. Brasília, 05 abr. 2010.

Supremo Tribunal Federal. AI 501573 AgR, Relator(a): Min. SEPÚLVEDA PERTENCE, Primeira Turma, julgado em 12/04/2005, DJ 26-08-2005 PP-00020 EMENT VOL-02202-12 PP02560.

. Supremo Tribunal Federal. RMS 24.823, DF, Relatora Ministra Ellen Gracie, julgamento dia 18/04/2006, Órgão julgador segunda turma, publicado no Diário de Justiça do dia 19 de maio de 2006.

. Supremo Tribunal Federal. Recurso Extraordinário n ${ }^{0} 306.938$ AgR, Relator(a): Min. Cezar Peluso, Segunda Turma, julgado em 18 de setembro de 2007. DJe-121 Divulgado em 10 de outubro de 2007. Publicado em 11 de outubro de 2007.

. Supremo Tribunal Federal. Acórdão nº RE 837.311/PI. Relator: Ministro Luiz Fux. DJe. Brasília, 18 abr. 2016.

. Supremo Tribunal Federal. MS 24.660, Relatora Min. Ellen Gracie, Relatora p/ Acórdão Min. Cármen Lúcia, Tribunal Pleno, DJe. Brasília, 23 set. 2011.

Supremo Tribunal Federal. RE: 598099 MS, Relator: Min. GILMAR MENDES, Data de Julgamento: 10/08/2011, Tribunal Pleno, DJe-189, Data de Divulgação: 30-09-2011, Data de Publicação: 03-10- 2011. REPERCUSSÃO GERAL - MÉRITO.

BINENBOJM, Gustavo. Uma teoria do direito administrativo: direitos fundamentais, democracia e constitucionalização. 3. ed. Rio de Janeiro: Renovar, 2014. 
CANOTILHO, Joaquim José Gomes; MOREIRA, Vital. Constituição da República Portuguesa anotada. 1. v. 1. ed. São Paulo: Revista dos Tribunais, 2007.

CANOTILHO, José Joaquim Gomes. Direito Constitucional e Teoria da Constituição. 7. ed. Coimbra - Portugal: Ed. Almedina, 2000.

DI PIETRO, Maria Sylvia Zanella. Discricionariedade administrativa na Constituição de 1988. 3. ed. São Paulo: Atlas, 2012.

ENGISCH, Karl. Introdução ao Pensamento Jurídico. 6. ed. Lisboa: Calouste Gulbenkian, 1988.

FERRAZ, Luciano. Concurso público e direito à nomeação. In: MOTTA, Fabrício (Coord.). Concurso Público e Constituição. $1^{\text {a }}$ ed. Belo Horizonte: Fórum, 2005. p. 245-255.

FORTINI, Cristiana; MOTTA, Fabricio. Concurso Público e Direito à Nomeação. In: PEREIRA, Flávio Henrique Unes et al (Coord.). $O$ direito administrativo na jurisprudência do STF e do STJ: Homenagem ao Professor Celso Antônio. Belo Horizonte: Fórum, 2014. p. 127-142.

FRANÇA, Vladimir da Rocha. Estrutura e motivação do ato administrativo. 1. ed. São Paulo, Malheiros Editores, 2007.

Invalidação judicial da discricionariedade administrativa no regime jurídico-administrativo brasileiro. 1. ed. Rio de Janeiro: Forense, 2000.

GUERRA, Sérgio. Discricionariedade Administrativa e sua Transformação no Estado Democrático de Direito. Revista da Faculdade de Direito Candido Mendes, Rio de Janeiro, v. 16, n. 16, p. 205-228, jan. 2011. Disponível em: 〈http://www.ucam.edu.br/portal/images/PDFs/revista_fdcm/Ucam16.pdf〉. Acesso em: 26 jun. 2017.

Discricionariedade administrativa - Limitações da vinculação legalitária e propostas póspositivistas. In: ARAGÃO, Alexandre Santos de; MARQUES NETO, Floriano de Azevedo (Coords.). Direito administrativo e seus novos paradigmas. Belo Horizonte: Fórum, 2012. p. 205-240.

MAURER, Hartmut. Allgemeines Verwaltungsrecht. 15. ed. Auflage. München: Verlag Beck, 2004.

MEDAUAR, Odete. O direito administrativo em evolução. 2. ed. São Paulo: RT, 2003.

MELlo, Celso Antônio Bandeira de. Curso de Direito Administrativo. 30. ed. São Paulo: Malheiros, 2013.

MORÓN, Miguel Sánchez. Discrecionalidad administrativa y control judicial. 1. ed. Madrid: Tecnos, 1995.

RICCI, Jean-Claude. Droit Administratif Général. 5e Edition. Paris: Hachette Superieur, 2013.

TOURINHO, Rita. O Concurso Público no Ordenamento Jurídico Brasileiro. 1 ed. Rio de Janeiro: Lumen Juris, 2009. 
Recebido em: 21/10/2017

Aceito em: 14/12/2017 
